\title{
History's Prison: Escaping the Temporality of the State-Still-To-Come
}

Daniel Jewesbury

\section{Q OpenEdition \\ 12 Journals}

\section{Electronic version}

URL: http://journals.openedition.org/etudesirlandaises/5035

DOI: 10.4000/etudesirlandaises.5035

ISSN: 2259-8863

\section{Publisher}

Presses universitaires de Rennes

\section{Printed version}

Date of publication: 30 November 2016

Number of pages: 149-161

ISBN: 978-2-7535-5358-3

ISSN: 0183-973X

\section{Electronic reference}

Daniel Jewesbury, « History's Prison: Escaping the Temporality of the State-Still-To-Come », Études irlandaises [Online], 41-2 | 2016, Online since 30 November 2018, connection on 22 April 2019. URL http://journals.openedition.org/etudesirlandaises/5035; DOI : 10.4000/etudesirlandaises.5035 


\title{
History's Prison: Escaping the Temporality of the State-Still-To-Come ${ }^{1}$
}

\author{
Daniel JeWESBURY \\ Ulster University
}

Abstract

The commemoration of the Easter Rising invokes a spectral nationalism which, in the Irish Republic, has for some years largely lain dormant. That invocation attaches itself all too easily to a call to "fulfil the destiny of the nation". This teleological obligation binds us to a future that has already been plotted, in the past. Against such moribund fulfilment of historical duty, it is possible to identify ways of escaping a doomed temporality, in the here and now.

Keywords: nationalism, history, space, public, feminism

Résumé

La commémoration du soulèvement de Pâques 1916 invoque un nationalisme spectral qui était resté en sommeil dans la République irlandaise depuis quelques années. Cette invocation ne rejoint que trop aisément la volonté d'en appeler à "accomplir la destinée de la nation", une obligation téléologique qui nous lierait à un avenir aux lignes déjà tracées, dans le passé. Contre l'accomplissement sclérosant d'un tel devoir historique, il est possible d'ouvrir des voies pour échapper à une temporalité fermée, dans l'ici et le maintenant.

Mots clés: nationalisme, histoire, espace, public, féminisme

\section{圈 Introduction}

The day was dying and the wind was sighing,

As I lay crying in my prison cell,

And the old triangle

Went jingle jangle

Along the banks of the Royal Canal ${ }^{2}$.

1. I would like to thank my colleague Dr. Robert Porter for absolutely invaluable comments and insight into this paper as it was developing, and Rachel Brown for help unpicking the ideas at an early stage.

2. Brendan Behan, Behan: The Complete Plays, London, Methuen, 2000, p. 104. 
Brendan Behan's play The Quare Fellow, a meditation on a condemned man's final hours in Dublin's Mountjoy Prison, emphasises the ways in which the routines and confines of the gaol combine to annihilate time: at various points in the play, verses of a song, "The Auld Triangle", are heard, sung offstage as if by the (always unseen) prisoner himself. The repetition of the chorus reminds us that the only rhythm in this life, the only punctuation, is the jangling of the triangle used to wake the prisoners every morning. Days pass identically, separated, one from another, by the ringing of the triangle. The words of the song, interspersed through the time of the play, introduce the idea - the possibility - of an elsewhere, a space that is outside prison-time, only for the triangle to reassert itself at the end of each verse, just as in the real prison it rang each day, the same way and at the same time.

The centennial commemorations of the Easter Rising have invoked the spectre of a certain kind of nationalism that, in the Republic of Ireland, might have been presumed to have passed away some time ago. The Nineteenth Amendment of the Constitution of Ireland, which followed the signing of the Good Friday Agreement in 1998, proposed relinquishing the Republic's territorial claim to the six counties of Northern Ireland; it was passed by a "Yes" vote of over $94 \%$ of those who voted. A little over a decade later, in 2011, after the collapse of the Irish economy and the popular disgrace of Ireland's ruling political class, Sinn Féin achieved their best election result in nearly 90 years; but only after the party in the Republic had taken pains to brand itself as a populist-left/anti-establishment grouping, distinguishing itself internally from its Northern wing (then administering British government cuts in the Northern Ireland Assembly). The one issue that, since the party's re-founding in the early 1970s, had always been its core demand, Irish re-unification, had little prominence in their election material. One could be forgiven for believing that following the Good Friday Agreement, the Celtic Tiger, and the economic collapse, the people of the Republic were not excessively concerned about realising the pre-ordained destiny of the nation.

Yet the innumerable books, conferences, newspaper articles and magazine features, television and radio dramas and documentaries, public events and artistic commissions currently examining "the legacy of the Rising" have all served to feed national speculation on the missed opportunities and thwarted aspirations of that now mythical rebellion" ${ }^{3}$. Schismatic historical events inspire many "true

3. It is unnecessary to list exhaustively the many outlets through which this commemoration has been realised - this journal is one of them. Let it suffice to say that the State commemorations were covered extensively by RTE and by broadcasters around the world, particularly in the UK; that every Irish newspaper carried extensive comment, opinion, feature articles, special supplements and historical reprints; that the National Museum of Ireland and the National Library of Ireland have had several special exhibitions and events; that innumerable State agencies have commemorated the Rising and that countless unofficial ceremonies have taken place too. 
heirs" and "revisionists". On the occasion of the commemoration of the Rising, historians, economists, politicians and commentators alike have examined exhaustively the ways in which successive rulers of the Free State and the Republic of Ireland, many of whom themselves took part in the events of Easter Week 1916, have failed to honour the spirit of the Rising in general, and the words of the Proclamation more particularly. Each writer lists their own special grievances, cataloguing the particular ways in which the State has betrayed its citizens, whether in terms of the organisation of the economy, the powers and duties that were abdicated by the State in favour of the Catholic Church, the continued oppression and subjugation of women, or any combination of these and other factors.

The dissatisfaction with the Irish State that has been given voice with the centenary of the Rising, then, has reintroduced the Proclamation to us as a document by which to hold contemporary politicians to account. We turn back to the Proclamation to discover the "true meaning" of Ireland, and to find some guidance on how we should reshape the "new republic" (it should be pointed out that there is, paradoxically, no evidence of any desire by the majority of citizens of the Republic to revisit the constitutional position of Northern Ireland, surely the most obvious and unquestionable anomaly to have arisen in the century since the Rising). The Proclamation, in the hands of those offering a contemporary gloss, reveals to us that Ireland was intended to be a profoundly progressive, egalitarian nation, and that its historical shortcomings have arisen because it has somehow been thwarted in its authentic becoming, after the decisive "moment" that was Easter 1916. This is the role of the Proclamation in these narratives: as a guarantee that is in turn an imperative. The "unfulfilled promise" thus becomes a weight upon our shoulders too, a destiny that we too have failed to honour, and that we have the burden of realising. We find ourselves caught within history, defining our future according only to our interpretations of the relics of the past. The triangle rings, and the new day that it heralds is the same as the one which went before it, and the one before that.

\section{From the teleological time of the nation to occupying the space of the Republic}

Elsewhere, I suggested a way of re-reading a peculiar document that has become more well-known with the commemoration of the Rising, the large sheet of paper that is known as the Half-Proclamation ${ }^{4}$. This was printed by members of the Dublin Metropolitan Police during their raid on Liberty Hall, on the

4. See Daniel Jewesbury, "The Constitution of a State Yet to Come: The Unbroken Promise of the Half-Proclamation" in Lisa Godson \& Joanna Brück (eds), Making 1916: The Material and Visual Culture of the Easter Rising, Liverpool, Liverpool University Press, 2015, p. 49-56. 
Thursday following the start of the Rising, 27 th April 1916. A small number of examples survive of this document, but the one about which I have written was that used in Seán MacDermott's court martial, which is stored with the rest of the surviving trial exhibits, in a dossier in the British National Archives in London ${ }^{5}$. The Proclamation was printed the day before the Rising began, with type requisitioned from a nearby print-shop, but so little could be found that it was necessary to print it in two halves. Accordingly, when the police raided the print works, they found the type as it had been set for the bottom of the document. Where the striking heading and the stirring, well-known first words of the Proclamation should be, the Half-Proclamation features only a blank space. This is a blank space, I've argued, that is pregnant with the possibilities of a "state yet to come", one into which, at a banal metaphorical level, we might write our own political aspirations, but which also has a more suggestive and potentially subversive meaning. This blank space is

a space which is waiting to be inscribed, not once but repeatedly. It is the blank space in which a future state can be constituted. It now comes to signify a disowned inheritance, an unremembered commitment to republicanism as a historical and political project. Once again, as before, it exercises a dreadful power, nothing less than the capacity to delegitimise the state as currently formulated. The image of the Proclamation that will doubtless be reprinted in multiple commemorative editions, at the behest of a political class who would wish to harness its very "meaningful meaninglessness" to their own ends, can be replaced with a genuinely empty space, in which there is no such hiding place ${ }^{6}$.

I want now to revisit this reading of the blank space, in the light of certain agonised revisions and re-imaginings of the Proclamation that have taken place since I originally wrote this passage. In its edition of Saturday 4th April 2015, the Irish Times commissioned six "new" Proclamations, to reflect the concerns of the people of Ireland today; the texts were written by a journalist, an environmentalist, a theatre director, a disability rights campaigner, an economist and an author ${ }^{7}$. The week before the official centenary commemorations, on the 15th March 2016, schools around Ireland held a "Proclamation Day", during which the Proclamation was read and studied; classes were encouraged to draft new proclamations and to submit these to a website maintained by the Department of

5. A Half-Proclamation was sold by Whyte's auction house in Dublin in March 2016 for $€ 8000$, and was described in the catalogue as one of fewer than 15 copies that were made (no source is given for this information). See [http://www.whytes.ie/13Main1wide.asp?Auction=20160313\&Lot $\left.=185 \& I M A G E=185 \_1\right]$.

6. Jewesbury, 2015, op. cit., p. 55-56.

7. [http://www.irishtimes.com/culture/heritage/time-for-a-new-proclamation-1.2164146]. The authors were Fintan O’Toole, Oisin Coghlan, Grace Dyas, Joanne O’Riordan, Constantin Gurdgiev and Gerard O’Neill. 
Education ${ }^{8}$. This apparently endless process of national navel-gazing (accompanied, for the schoolchildren, by flag-raising and singing of the national anthem), has seen a revolutionary manifesto, one which asserts its legitimacy by an appeal to Ireland's "dead generations", and which promises to achieve its goals through armed insurrection, transformed into a series of banal, aspirational "mission statements". Both the Irish Times's reprises, and the examples drafted and uploaded by hundreds of schools around the country, are couched in the rights-centred language of so many bureaucratic equality policies and organisational codes of conduct ${ }^{9}$. As must be expected from a programme delivered by a government department as part of an official State commemoration, the children's proclamations effectively do the exact opposite of their venerated progenitor: where the Proclamation sought to sweep away the illegitimate domination of a whole people by the ruling class of a foreign nation, the contemporary proclamations tinker at the edges of a political dispensation that they cannot dream of displacing (indeed, they are written at the behest of the State itself), pleading meekly for "respect", "justice" and "equality". Where the Proclamation, underwritten by the force of arms, functioned as a kind of auto-commentary on the means by which it was simultaneously being actuated, today's revisions exist entirely in a rhetorical and political vacuum.

I want to refocus and refine my attention, then, not on making the blank space of the Half-Proclamation a placeholder for trite wish-lists, but on thinking about how it might yet enable us to move from the exclusively historical-teleological project that the commemorations have engendered. This historical-teleological project requires us to place ourselves, simultaneously, in Easter Week 1916 (here defined as a uniquely historically authentic "moment" or "event"), trying to divine the diverse desires of the socialists, feminists, republicans and nationalists who proclaimed the Republic, and in a present that has been evacuated of its own political contexts and significance, trying to work out how to reconcile those varying aims in an authentic manner 100 years after the fact. Instead of this, I want to attempt to imagine and occupy alternative spaces within the two actually-existing political entities of contemporary Ireland. In short, I want to move away from nationalist-teleological time, which Irish governments of whichever hue can afford to luxuriate in in perpetuity, and toward a consideration of the (plural) spaces of the (plural) Irelands, spaces which people in Ireland occupy or aim to occupy.

What follows is somewhat polemical and some of it is doubtless less rigorously substantiated than it might be; I want to present an initial set of intuitions and observations that, I hope, might serve as a basis for further study. However, I

8. [http://www.ireland.ielevents/proclamation-day-2010].

9. [https://www.scoilnet.ie/proclamationtemplate/]. 
have in my mind the words of the feminist geographer Doreen Massey, who died as this paper was being written, and who insisted throughout her work on the spatial construction of the social (the reverse having already been widely accepted, within radical geography, in the 1970s $)^{10}$. I'm thinking of space here not merely as a clever or convenient rhetorical or metaphorical device, an axis to pose against the relentless temporality that I've said characterises nationalism. The "flattening" of political desire toward a teleological trajectory that, like Zeno's arrow, never reaches its target, constitutes a genuine conceptual and political impoverishment. Following (and sometimes, crucially, departing from) Henri Lefebvre, Massey seeks to understand processes of historical-materialist struggle as being fought in and over space, over access to and control of literal and figurative spaces in contemporary society - the space of the public sphere and the public sector, in which individuals might meaningfully form communities of interest and discover intersectional solidarities; the literal public space of our cities, spaces in which we might construct ways of being, communally, beyond the commodified reach of labour-time (in the workplace), the regulating order of consumption (in the spectacular space of the shopping centre) and the constricting social bonds of the private space of the family; and, in concert with these, spaces of resistance and rupture, where we can begin to set up parallel or alternative structures, where we can occupy the "blank spaces" evacuated by the State as it retrenches and privatises $^{11}$. In the spirit of Massey's exceptionally important work, the point of this paper is not simply to reprioritise space and thereby denigrate the critical importance of temporal perspectives, but to distance oneself from a kind of teleology, and a conceptualisation of time, which takes no place, which exists only in the abstract; which, moreover, in the midst of so much State-sponsored commemoration, becomes framed in pseudo-historical discourse as a way of actively avoiding contemporary social relations. The defence of the public, the social, the realm of "lived experience", and the concentration on the possibility of redefining social relations, are far more urgent tasks than any perceived filial obligations to the destiny of the nation.

I'd like to return, before moving on, to the motif of the triangle, but this time instead of beating out the inexorable advance of prison-time, it points us to a conceptual triad: instead of the simplistic intersection of axes, the juxtaposition of the $x$ and $y$ of historical time versus a baldly-stated "space", we have three potential dimensions - firstly, the public, which here stands metonymically for the social, configured in space; secondly, the body, which here represents a problematic

10. Doreen Massey, "Politics and Space/Time" in Space, Place \& Gender, Cambridge, Polity Press, 1994, p. 249272. See also Massey, Spatial Divisions of Labour: Social Structures and the Geography of Production, Basingstoke, Macmillan, 1984.

11. Henri Lefebvre, The Production of Space, Oxford, Blackwell, 1991. 
of individual sovereignty within the disciplinary space of the State, and the way in which that discipline (and the possibility of resistance to it) is inevitably embodied; and thirdly (and, for the moment, most vaguely), the political, as a realm of action which is activated by the preceding two terms, and which can only take place in space, in a tense of "present space", a here-nowness to which I'll return toward the end of this paper.

In positing this triad, I'm very much aware of Lefebvre's own triadic concept of space, which talks of "objective space" (the supposedly empirical space of the plan or the map, "neutral" physical space), "conceived space" (or "representations of space", mental, ideal or ideological space) and "lived space" (the product of the first two - the space of lived experience) ${ }^{12}$. I'm also conscious of Lefebvre's injunction to give an adequate account of the experience of the body within social-spatial disciplines, to understand how space is embodied and how it is bodies that perform the interaction in social space ${ }^{13}$.

\section{In the blank space of the public square}

In considering what might be at stake in "the public" in contemporary Ireland, and how that space is compromised in the context of state commemoration and other parades, we need to clarify some terms. I will use a shorthand that purists of political theory might baulk at, eliding concepts that are strictly separate but which I want to consider in relation to one another. When I speak of the "public", I'm drawing inevitably on the notion of a (bourgeois, rational, discursive) public sphere, as developed by Jürgen Habermas and others, a historical space of beingin-common that arises with the transition from feudal or absolutist systems of government to early bourgeois democracies: the venues where men could gather and construct new forms of sociality, and which also give rise to an abstract (or virtual) space of discourse ${ }^{14}$. But my notion draws in terms that are traditionally only vaguely related to Habermas's public sphere: the idea of a "public sector", of infrastructural, productive and bureaucratic assets and enterprises, public goods owned and controlled by the State in the name and for the benefit of its citizens; and finally the concept, perhaps most under-theorised of this triad, of public space, which is to say (predominantly urban or quasi-urban) space to which "members of the public" have some settled, minimally regulated right of access,

12. Ibid., p. 33.

13. Ibid., p. 173-174.

14. Jürgen Habermas, The Structural Transformation of the Public Sphere: An Inquiry Into a Category of Bourgeois Society, Cambridge, Polity Press, 1989; see also Nancy Fraser, "Rethinking the Public Sphere: A Contribution to the Critique of Actually Existing Democracy", Social Text, n' 25/26, p. 56-80; Chantal Mouffe, The Democratic Paradox, London, Verso, 2000; Simon Sheikh, "In the Place of the Public Sphere? The World in Fragments", Transversal, vol. 6, 2005 [http://transversal.at/transversal/0605/sheikh/en]. 
which is not owned or controlled for profit, and from which they can only be alienated by its transfer to private hands.

We have a nexus, then - of (a) pseudo-public communicative space (I say pseudo-public since, whilst its pronouncements are publicly-accessible published - its channels are quite likely to be privately owned and regulated; even many originally "alternative" online media channels have recently been subject to concentration of ownership and substantial corporate investment), (b) the public assets of the State, and (c) actual public space, in which citizens can gather and associate without excessive regulation, and without reference to spaces of consumption. This complex, multi-valent "public", touching the citizen in many different ways, constitutes for me a set of prerequisites. Prior to any possibility of collective "being-in-public", of what we can now call publicness (an awkward English translation from a German word, öffentlichkeit), is this set of public properties, which it is crucial to be able to act within and to defend, since it is, as I've suggested, the precondition of political action.

In the Irish and Northern Irish neoliberal states, from the late 1990s onward, we are confronted with only slightly contrasting processes of privatisation of the public. In Northern Ireland the paramilitary ceasefires and the signing of the Agreement heralded a new economic era centred around private property speculation, similar to the rapid processes of private accumulation and deregulation which had happened in former Socialist countries in central and eastern Europe after 1989: in the North, however, private capital accumulation was given an added moral urgency, with trickle-down economics presented as the only means to underwrite peace ${ }^{15}$. In the Republic, a historically depressed economy, dependent on subsidy from Europe, also discovered property speculation and neoliberal economics, centred around low corporate taxes, massive personal and corporate debt, and very high consumer spending. In both regions the rapid transformation of the economy signalled a new era of "primitive accumulation"16. David Harvey has described in detail the process by which post-industrial cities, no longer capable of creating surplus value through production, have been financialised and leveraged, sold and resold as packages of debt which produce short-term, deterritorialised profit (the huge and continuing disparity between the Republic's Gross National Product - crudely, the size of the economy that stays within

15. Daniel Jewesbury and Robert Porter, "On Broadway" in Jewesbury, ed., The Centrifugal Book of Europe, Belfast, Centrifugal, 2010; Daniel Jewesbury, Infantile City: Inside, Outside, Ljubljana, Likovne Besede, 2010; Daniel Jewesbury, "Belfast: Our Time, Our Place", Edinburgh Review, nº 136, 2012.

16. Karl Marx, Capital: A Critique of Political Economy, Volume 1, London, Penguin Books, 1990, particularly chs. 31-33. Marx is referring specifically to the early Acts of Enclosure by which common land in England was privatised from the $15^{\text {th }}$ century onward; in the contemporary setting, the private appropriation of once-public urban land, carried out with the political support and financial assistance of state agencies, constitutes a new era of enclosures. 
the borders of the nation - and its Gross Domestic Product - which includes all wealth that is expatriated to foreign owners - is striking here; since the economic crash of 2007, there are times when Ireland has said to be "recovering", according to its GDP, while still in recession, according to its GNP) ${ }^{17}$. The financing of development is itself now the major means of producing profit: and the fads which fuel new capital investments, from the cultural tourism which came to prominence in the late 1990s, to various global sporting spectaculars and, most recently, university infrastructure (including many highly profitable new student accommodation projects), are merely the means to move sums from one side of the balance sheet to the other. It is now possible to consider entire cities as single, massively complex financial instruments. As Harvey shows, the cities participating in this neoliberal spectacularisation of urban form are forced into competition with one another for the slender civic returns of so much investment of public infrastructure: the "bed-nights" and "visitor spend" so impossible to quantify, but which nonetheless are "calculated" according to spurious, self-serving metrics devised by the major accountancy consultancies whose figures and services underpin the contemporary competitive cities (and who work for all the competitors equally $)^{18}$. The more urban actors attempt to distinguish themselves from one another via their unique "offer", the more they all become the same: crowded with the same heritage quarters, theme bars, landmark cultural venues, the same riverside restaurants and consumer experiences.

\title{
圏 In the female prison ...
}

\author{
In the female prison \\ There are seventy women \\ I wish it was with them that I did dwell, \\ Then that old triangle \\ Could jingle jangle \\ Along the banks of the Royal Canal ${ }^{19}$.
}

One of the commissions to have arisen from the Arts Council of Ireland's open call for artistic examinations of 1916 is a collaboration between artists Sarah

17. David Harvey, A Companion to Marx's Capital, London, Verso, 2010; David Harvey, Rebel Cities: From the Right to the City to the Urban Revolution, London, Verso, 2013, particularly chapters 1, 3 and 4. For a historical account of the history of the neoliberal redevelopment of the post-war city see Rachel Weber, "Extracting Value from the City: Neoliberalism and Urban Development", Antipode, vol. 34, n 3, p. 519-540. For Ireland's GNP/GDP disparity, see [http://socialdemocracy21stcentury.blogspot.co.uk/2010/09/irelands-sham-recovery-gnpversus-gdp.html] and [http://bilbo.economicoutlook.net/blog/?p=10521]. See also Conor McCabe, The Sins of the Father: Tracing the Decisions that Shaped the Irish Economy, Dublin, The History Press Ireland, 2013.

18. D. Harvey, Rebel Cities: From the Right to the City to the Urban Revolution, op. cit., ch. 4.

19. B. Behan, Behan: The Complete Plays, op. cit., p. 124. 
Browne and Jesse Jones entitled In the Shadow of the State. The project, which takes place across 2016 in spaces in Derry, Liverpool, Dublin and London, examines the manner in which women are situated within the contemporary Irish "body politic", through co-production with experts from the fields of law, medicine and design, as well as musicians and performers. The image of a "shadow" simultaneously conveys two dissonant meanings; it calls to mind both the subordinate position of women, shadow-citizens of Ireland, as defined through the legal mechanisms of the State, but it also invokes a potential challenge to the State itself, a disordely growth that comes from within, that inserts itself into official discourse with the hope of eventually displacing it.

It's notable that one of the themes of the commemoration, in various media, has been the recuperation of the significant role played in the Rising by women ${ }^{20}$. One of the reasons, arguably, that this gesture at feminist revisionism has been thought so necessary is that the exclusion of women from the institutions of the Irish State (and its provisional predecessors) began so soon after the suppression of the Rising; and the reason why it is considered so urgent is that it continues to this day ${ }^{21}$. The $41^{\text {st }}$ Article of the Irish Constitution privileges

the Family as the natural primary and fundamental unit group of Society, and as a moral institution possessing inalienable and imprescriptible rights, antecedent and superior to all positive law... The State, therefore, guarantees to protect the Family... as the necessary basis of social $\operatorname{order}^{22} \ldots$

20. See, for example, the following articles in Irish and international media: Una Mulally, "Why Women Have Risen to the Top in 1916 Lore", Irish Times, 28 March 2016 [http://www.irishtimes.com/opinion/una-mullallywhy-women-have-risen-to-the-top-in-1916-lore-1.2588980; Sadhbh Walshe, "The Forgotten Heroines of Ireland", New York Times, 18 March 2016, p. A27; Jim Gibney, "Celebrating the Role of Women in the 1916 Easter Rising”, Irish News, 30 March 2016 [http://www.irishnews.com/opinion/columnists/2016/03/30/news/ celebrating-the-role-of-women-in-the-1916-easter-rising-466171/; Jayne McCormack, "How Winifred Carney Became James Connolly's Confidante”, BBC News, 27 March 2016 [http://www.bbc.co.uk/news/uk-northernireland-35849250]; see also RTE's documentary Seven Women [https://1916.rte.ie/risingonrte/seven-women/].

21. For a short commentary, written in the context of the commemoration, see Olivia O'Leary, "Why, 100 Years After the Rising, Are Irish Women Still Fighting?", The Guardian, 25 March 2016. [http://www.theguardian. com/commentisfree/2016/mar/25/100-years-after-easter-rising-irish-women-still-fighting-gender-equality]. Also see Fidelma Ashe, "Gendering War and Peace: Militarized Masculinities in Northern Ireland", Men and Masculinities, vol. 15, $\mathrm{n}^{\circ} 3$, 2012, p. 238: "British colonialism in Ireland provoked notions about the feminisation of Irish men. This concern... was reflected in the discourses of the Irish hero Patrick Pearse ... Pearse stated that 'a nation which regards [bloodshed] as the final horror has lost its manhood' [...] The call to arms in defence of the Irish nation was therefore very much 'a call to manhood'. The coupling of the ideals of masculinity to physical force violence framed certain forms of masculinity as the medium through which the nation could be restored and framed the national struggle as the medium through which Irish 'manhood' could be restored." (my emphasis).

22. Constitution of Ireland / Bunreacht na hÉireann, October 2015 text, Article 41 [http://www.taoiseach.gov.ieleng/ Historical_Information/The_Constitution/Bunreacht_na_hÉreann_October_2015_Edition.pdf]. 


\section{It continues:}

In particular, the State recognises that by her life within the home, woman gives to the State a support without which the common good cannot be achieved... The State shall, therefore, endeavour to ensure that mothers shall not be obliged by economic necessity to engage in labour to the neglect of their duties in the home ${ }^{23}$.

The Constitution, then, is very clear: women's primary duty to the State is as mothers; the place in which they do this is the home (that is to say, they are not admitted into the public sphere, or recognised as public beings); and the institution of the family is the disciplinary mechanism through which their lives are to be regulated, in the service of the State, in the home. (And as O'Leary notes, the injunction against labour outside the home was enforced not by subsidising women in the home, but by disadvantaging them in, and even barring them from, the workplace.)

The Constitution marks the boundaries of the space of women within the Irish State, but it is merely the most basic codification of their subjecthood; it is circumscribed by myriad complex legal and medical practices around reproduction, contraception, marriage, fertility and medicine; numerous ways in which women's bodies are clinicalised, subjected to law, or to other (public) professional male discipline. Many of these practices and discourses pre-date the State, originating in $19^{\text {th }}$ century British law (the 1861 Offences Against the Person Act was the statute defining abortion law in Republic until 2014; it still fulfils that function in Northern Ireland. In Great Britain it was repealed with the passing of the 1967 Abortion Act). Expedient anti-colonial State rhetoric notwithstanding, colonial provisions for the medicalisation and treatment of women's bodies have very often only been reformed in response to legal challenges (often from European courts), and have usually been amplified and augmented.

Browne and Jones envision their project as a para-legal mechanism: a way of incorporating a female space, from which to explore "how the law has touched women's lives and bodies", and from which to return that touch ${ }^{24}$. In each venue the artists are establishing a "legal drafting session" with academics, activists and lawyers, exploring the interwoven histories of capitalism, gynaecology and law within the State. Following these private sessions, the artists then work with collaborators to realise a public action in each location. The actions perform the critique of the Irish and Northern Irish states, in the disciplinary spaces which give them ideological currency: the home, the hospital, the lecture theatre. 
Browne and Jones's fundamental question throughout this project is whether there can be a feminist practice of law, and how this would need to be constructed with reference to other alternative publics or "counterpublics" within the State.

\section{Conclusion}

I remarked earlier on the curious immediacy of the Proclamation; it is not a set of demands, a manifesto, or a plea for recognition. It is, as I have described it, an "auto-commentary". It narrates the actions that are taking place behind it, in the GPO, and across Dublin, at the moment when it's being read out: the violent rejection of foreign rule, actuated in the present. I've also described the the defence of the public as something that can only be done through occupation of that public, through the activation (or, following Browne and Jones, the "performance") of the "nexus" of public discourse/public assets/public space, as a prerequisite of constructing the event that becomes "political"; I want to suggest that a similar process can be at work here, that, rather than seeing in the Proclamation a historic relic, requiring recontextualisation and redrafting by newspaper columnists and schoolchildren, that we can discover in the urgent act of its very proclamation, an affirmation of the "here and now" that must be its "legacy" to us today. I also want to return to that "blank space" in the Half-Proclamation.

Throughout this text I have been defining triads, of spaces and of the public. I want to return now to the consideration of temporality with which I concerned myself at the outset of this paper, and suggest yet another triadic arrangement, concerned now with the interpenetration of "space" and "time". I have already defined two kinds of time: firstly the revolutionary time of 1916, an imagining of a future that is always to be fulfilled; secondly, the self-regarding, teleological stasis of 2016, revisiting and revising 1916 and situating it almost atemporally, "luxuriating in perpetuity" in the time of Zeno's Arrow; the final dimension I want to suggest is a four-dimensional space-time which is the political possibility of the present moment, an urgent, unfolding, embodied and located moment in which we are, in the formulation of Alain Badiou, both actor and target ${ }^{25}$. Thinking about the character of the "event" in relation to his own participation in May '68, Badiou writes:

[W]e were actors, but actors absolutely seized by what was happening to them, as by something extraordinary, something properly incalculable... [I]f we add up all the anecdotes one by one, we can always say that at any given moment there were certain actors, certain people who provoked this or that result. But the crystallization of all these moments,

25. On "space-time", see D. Massey, "Politics and Space/Time", art. cit. 
their generalization, and then the way in which everyone was caught up in it, are well beyond what any one person might have thought possible... None of the little processes that led to the event was equal to what actually took place...; there was an extraordinary change of scale, as there always is in every significant event... Lin Piao... once said, at the height of the Cultural Revolution, that the essential thing was to be, at a revolutionary conjunction, both its actor and its target. I quite like this formula. Yes, we were actors, but in such a way that we are targeted by, carried away by, and struck by the event. In this sense there can undoubtedly be collective events ${ }^{26}$.

This is a necessarily cursory reference to a theorisation of the event that, in Badiou's work, is complex and far-reaching. I want merely to suggest that the possibility of being both actor and target, of having a capacity to be decisive and of there being some necessity for one's action, at the moment, here, begins to allow us to conceptualise an injunction that reaches beyond the "jam tomorrow" of a static, convenient teleology, and the post-revolutionary burden of a history betrayed. The empty space of the Half-Proclamation contains the spirit of this injunction, but it is not a duty that is inscribed in any way in its venerated, anomalous expanse. Rather, the absence of that duty, the irrelevance of History's deadening temporality to the exigency of our struggle, invites us to gather, to define and defend the public, and from it to find the political, the moment in which our action can be most precisely targeted.

26. Badiou, quoted in Peter Hallward, Badiou: A Subject to Truth, Minneapolis, University of Minnesota Press, 2003, p. 123. 